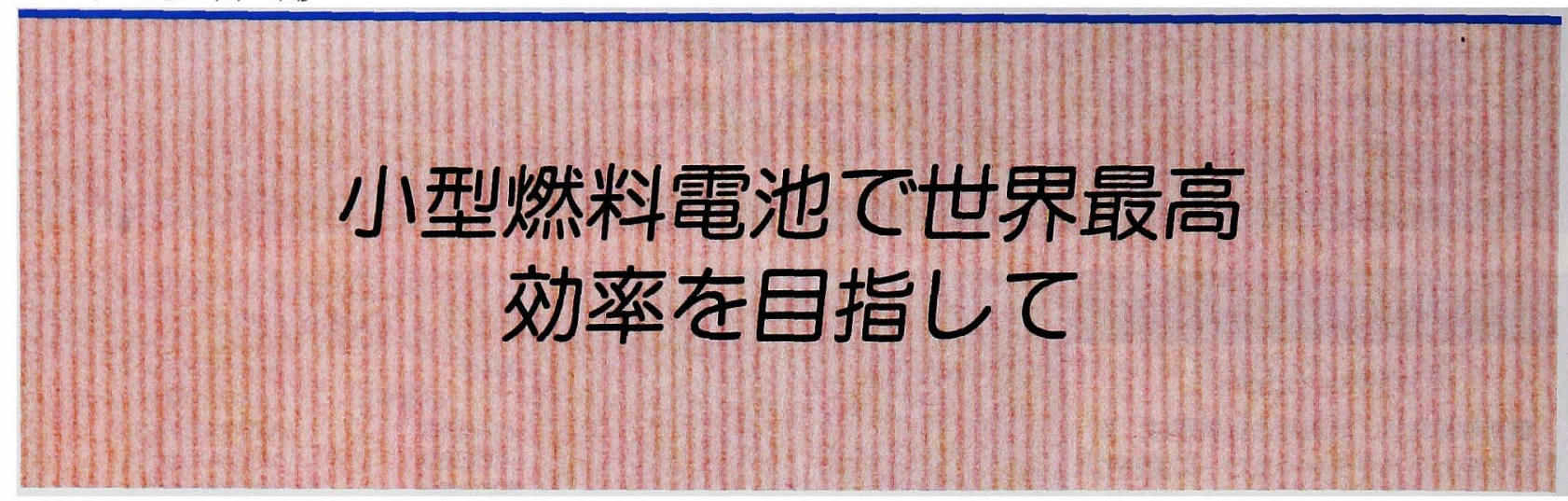

1.はじめに

これからの社会や技術の発展の一つのキーワードとして 分散化が挙げられるが，エネルギーもまた分散化による発 展が期待されている。日本のエネルギー源の海外への依存 率が高いことから，ほかの先進国と比較してもエネルギー 供給構造は脆弱である。そのため今後とも化石燃料に依 存することなく，かつエネルギ一源の多様化を図る観点か ら, 新エネルギーを導入し, 各エネルギーのベストミック スを実現することが重要となる。

そこで期待されているのが燃料電池である。特に関西電 力 (株) が取り組んでいる固体酸化物形燃料電池（SOFC： Solid Oxide Fuel Cell）は，発電効率が高く環境性にも優 れており，高温排ガスによる複合発電でさらに高効率を狙 える発電システムとして有望視されている(図1)。 SOFC は作動温度が一般に $1,000^{\circ} \mathrm{C}$ 付近のため, 使用でき る材料が制限されコスト高となるなどの課題があるが，関 西電力では課題解決のため「低温作動化」に取り組み, $800^{\circ} \mathrm{C}$ 以下の低温で作動する SOFC としては世界最高レべ ルの出力密度を実現するセルの開発と $1 \mathrm{~kW}$ 発電モジュー ルの開発に成功し, 新エネルギー実験棟（図 2）での発電 試験においては最高効率 $45.1 \%$ を達成している。

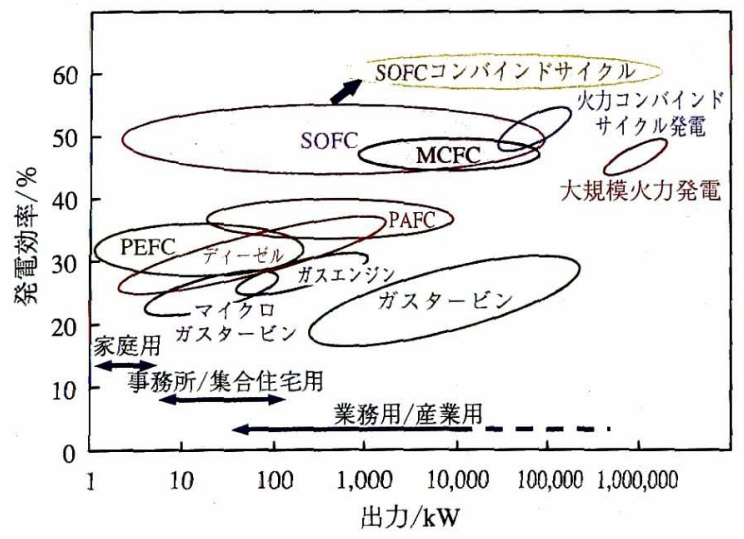

図 1 各種発電システムの発電効率
今回，関西電力エネルギー利用技術研究所のご厚意によ り, 世界最高レベルの発電効率を達成した $1 \mathrm{~kW}$ 級低温作 動SOFC コジェネシステムを見学取材させていただいた。

\section{2. 燃料電池とは}

燃料電池の歷史は以外に古い。1801 年イギリスのDavy が炭素電極を使用するという原理の発見に始まり，1839 年に注同じくイギリスの Grove が水素一酸素電池の実験 を行っている。また 20 世紀前半には現在の燃料電池の原 型となる酸素水素型電池の実験も実施されている。近年の 燃料電池の研究開発は，産業用・民生用として定置用・自 動車用燃料電池へと進展しており, 我が国においても 1981 年より国家プロジェクトとして研究開発が続けられ ている。

燃料電池は燃料である水素と酸化剤である酸素を化学反 応させて水を発生させる過程から直接電気を発電する装置 である。「電池」という名前はついているが蓄電池のよう に電気を充電しておくものではなく，燃料である水素を天 然ガスやメタノールを改質して作り，大気中の酸素を取り 入れ反応させる「発電機」である。また，発電と同時纪熱 もエネルギーとして生かすことでエネルギー利用効率も高 められている。

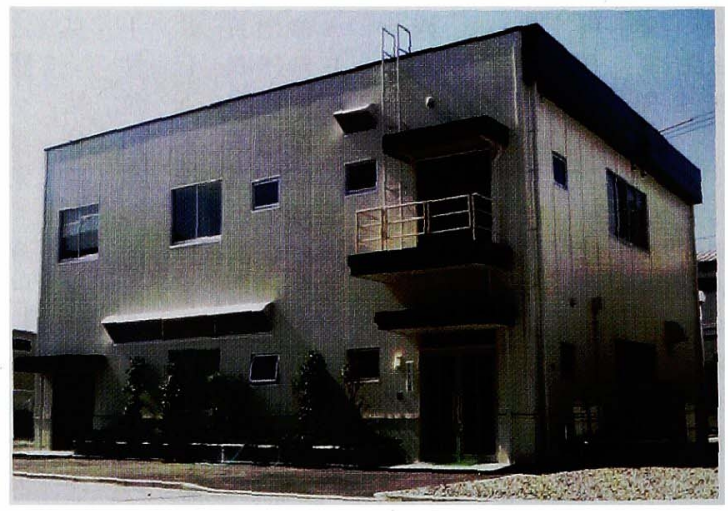

図 2 関西電力新エネルギー実験棟の外観 


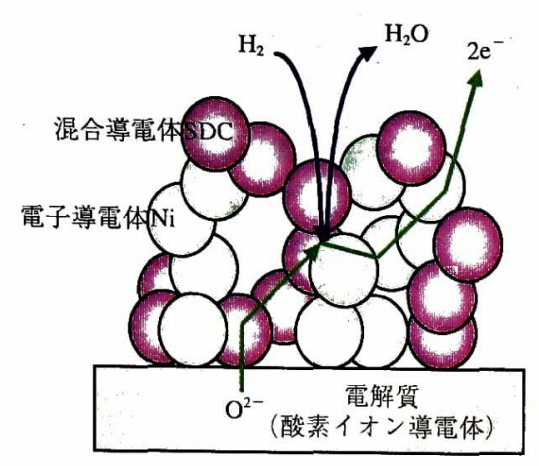

図 3 高性能燃料極

\section{3. 関西電力における低温作動 SOFC の開発}

\section{1 新たな構成部材への挑戦}

関西電力では, 1995 年に低温作動 SOFC の研究をス夕 一トさせている。当時, 大学などの研究機関を中心研究 が行われていた SOFC の低温作動化を研究テーマとして 選んだのは，この領域では従来と異なる新しい高性能材料 を適用できる余地が大きく, SOFCのさらなる高性能化 と低コスト化の可能性が大きいと期待されたからだそうで ある。研究開発にあたり, セル材料, セル, スタック，モ ジュール, システムの各開発ステップを進む道のりでは, メーカのみに頼らず試行錯誤を繰り返しながら独自に研究 をされている。また，このような取り組みは電力会社とし ては珍しく，今後の会社の一つの方向性を示唆するものと 考えられる。

一般に SOFC は十分な電池性能を得るには， $1,000^{\circ} \mathrm{C}$ 付 近の高温が必要であり，構成材料は主としてセラミックス であった。しかし, 高温で発電効率が高いがゆえに材料面 での課題が残る。すなわち, 構成材料の選択肢が狭く, 熱 劣化が起こりやすい。また, 熱応力により㔀離や割れが起 こる。そこで, 2001 年度より三菱マテリアル(株)との共 同研究として, 作動温度を $650 \sim 800^{\circ} \mathrm{C}$ に低減した低温作動 SOFCの開発に取り組まれている。この温度領域は，金属 系材料が使えること, 内部改質が可能であること, 複合化 にも適用可能であることから設定されている。この共同研 究で，両社がそれまで培ってこられた要素技術を組み合わ せて最適化を進め, 高性能化へのブレークスルーを実現で きたそうだ。この低温化によるメリットを以下に挙げる。

・低温化により材料選択の幅が広がり, 低コスト化が図 れる。作動温度が $800^{\circ} \mathrm{C}$ 以下であるため, 発電セルの 積層に用いるセパレー夕に安価な金属材料が使える。

- 構成部材の熱的劣化が軽減され高信頼性化・長寿命化 につながる。同時にシステム全体の耐熱要求度も緩和 され，補機類など設備の低コスト化が可能となる。
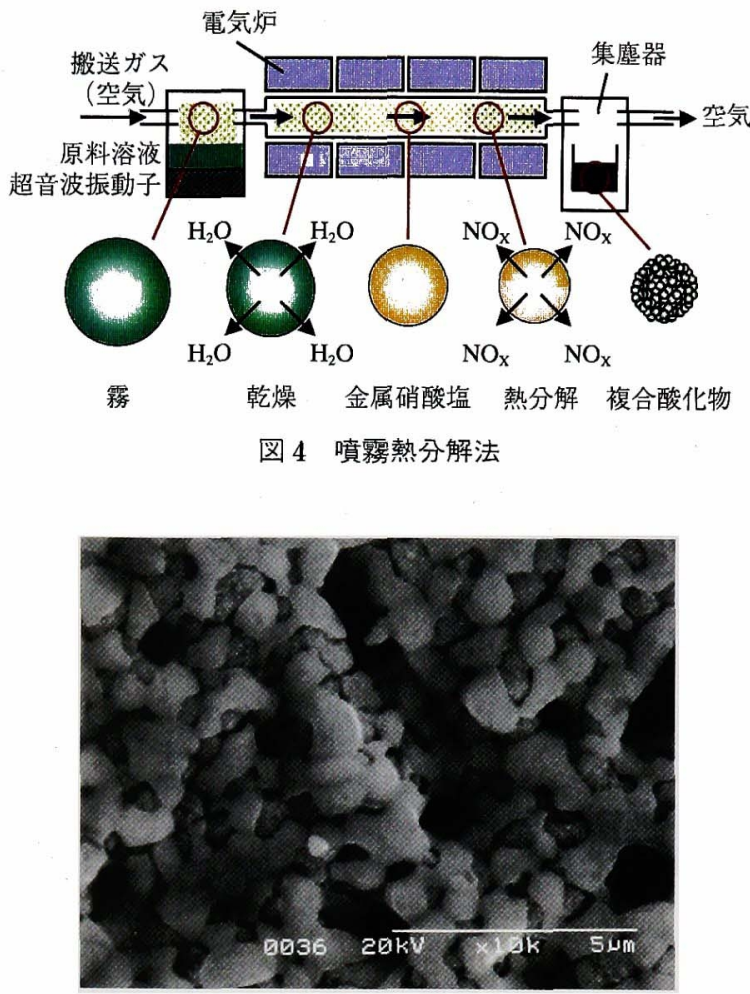

図 5 複合微粒子による燃料極の表面微構造

・作動温度を $600^{\circ} \mathrm{C}$ 以上に設定すると，メタンなど燃料 の水素への改質が SOFC 内部で可能であり, システ ムのコンパクト化や簡素化が可能である。

しかし，通常のセルであれば，温度が下がるとともに電 解質のオーム抵抗や電極反応抵抗などの内部抵抗が増大し てしまい発電性能が低滅してしまう。そこで，実用的な低 温作動 SOFC の実現には, 電解質の導電率向上や薄膜化 ならびに電極の高活性化により，低温でも高性能なセルの 開発が重要な課題となっていた。

\section{2 高性能セルの開発}

高性能なセルの開発にあたり，(財) ファインセラミック スセンターと共同で燃料極の高活性化に取り組み，新規で 高性能なセル部材を組み合わせることで高性能燃料極（図 3）の開発に成功したそうだ。

この燃料極では，酸素イオンの移動促進と電極反応場の 拡大を水らい，低温でも高い酸素イオン導電性を示し，氻 つ燃料極雲囲気下に電子と酸素イオンの混合導電性を実現 するセリア系酸化物（SDC：Samaria Doped Ceria）を採 用している。また，SDC とニッケル酸化物が一つの粒子 中に共存する $\mathrm{NiO}-\mathrm{SDC}$ 複合微粒子を, 化学組成が均一 でサブミクロン〜数ミクロンオーダの粒度分布の揃った球 状粒子が生成可能な噴霧熱分解法（図 4）により合成し, これを電極用出発物質として用いている。この複合微粒子 


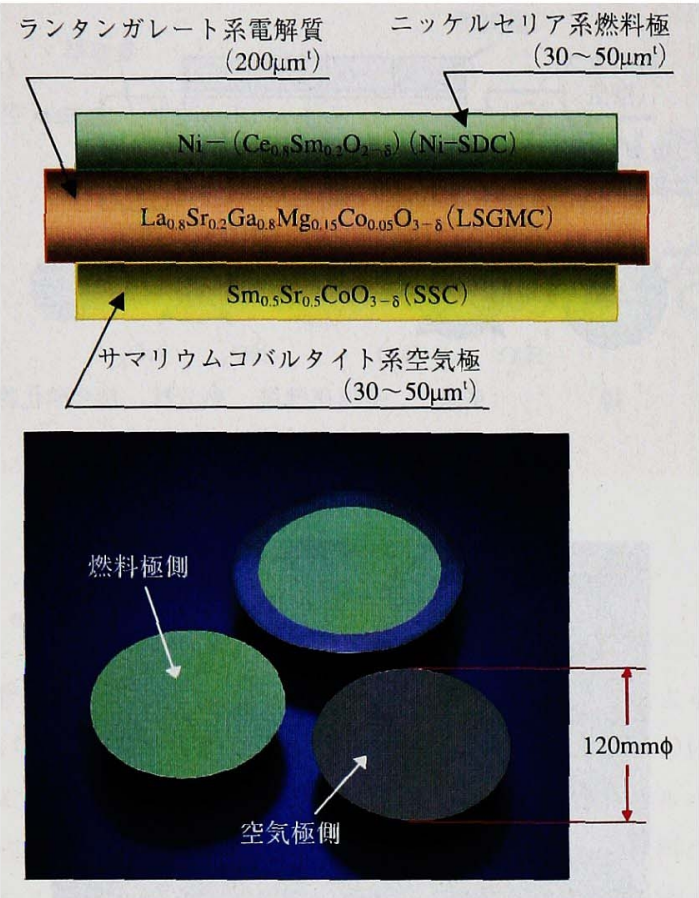

図 6 セルの概要

の電解質への焼付け温度を最適化して, $\mathrm{Ni}$ と SDCのネ ットワークが互いに絡み合う微細な電極構造を実現してい る(図 5)。

また, 電解質としては大分大学と三菱マテリアル(株)が 開発した高酸素イオン導電性ランタンガレート系電解質 （LSGMC: Doped Lanthanum Gallate Electrolyte) を採 用している。これは，導電率が非常に大きいために作動温 度を下げても電解質として十分性能を発揮するためであ る。これを，材料粉を薄膜シート状に形成する方法である テープキャスティング法により $100 \mu \mathrm{m}$ まで薄膜化してい る。また，空気極には高い酸素還元能を有するコバルタイ 卜系酸化物（SSC：Samarium Cobaltite Compound）を 用いている。

さまざまな要素技術を組み合わせた電極面積 $2 \mathrm{~cm}^{2}$, 電 解質厚みわずか $0.1 \mathrm{~mm}$ である 1 枚 1 枚の単セルは, 言 うまでもなく研究者の方々の汗の結晶である。モジュール を作る際には，上記単セル技術を活用した実用サイズセル （図 6）を 46 枚積層してスタックとしている。単セルの発 電特性（図 7) は, セル電圧 $0.7 \mathrm{~V}$ に対する出力密度が $800^{\circ} \mathrm{C}$ で約 $1.8 \mathrm{~W} / \mathrm{cm}^{2}, 700^{\circ} \mathrm{C}$ で約 $0.9 \mathrm{~W} / \mathrm{cm}^{2}$ と, 低温作 動 SOFC としては極めて優れた発電特性を有している。

スタックュニットの構造（図 8）は，セルの上下を集電 体とセパレータで挟んだシールレス構造を採用している。 セパレータは低温作動の特徴を生かして金属セパレータを 使用し，集電体は燃料が電極内部までスムーズに供給され るよう多孔質な構造となっている。また，余剰の空気およ

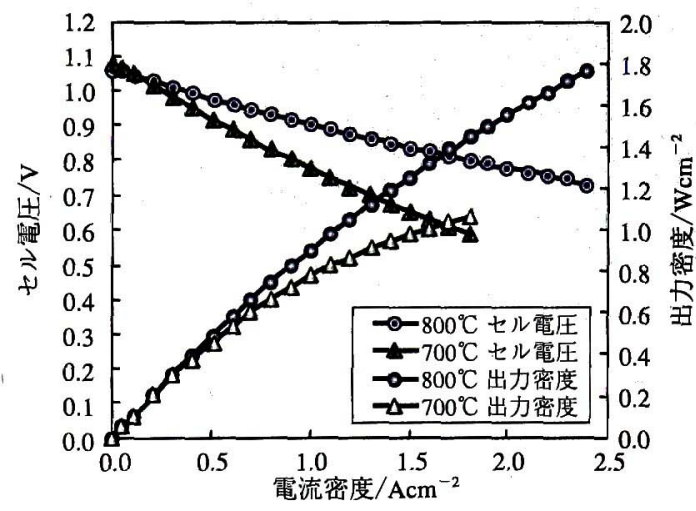

図 7 単セルの発電特性

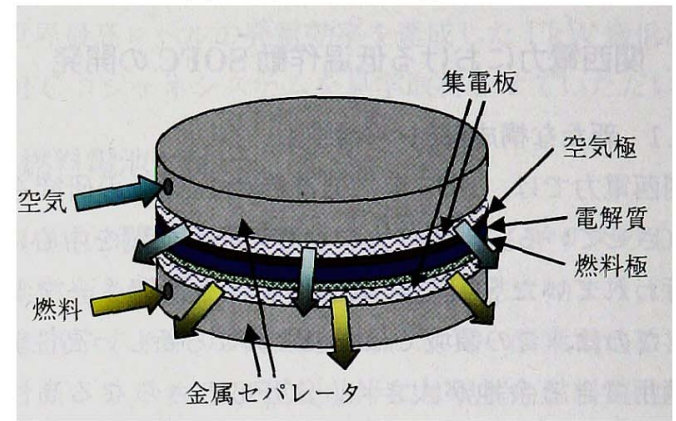

図 8 スタックュニットの構造

び未反応燃料は，シールレス構造であるためスタックの外 縁で混合・燃焼し，その燃焼熱はスタックのジュール熱と ともにモジュールの温度維持のための熱源として有効利用 されている。

このようにSOFCの低温動作のために新規材料を採用 したため, 試行錯誤の連続で，複合微粒子とその処理方法 による実験を繰り返すたびに新しい発見や性能が得られた そうである。この高性能材料の開発に最も苦労されたとの ことであるが, 低温作動 SOFC としては極めて優れた発 電特性を達成されたことは，まさに Nothing ventured, nothing gained であり研究開発の醍醐味を感じた。

\section{4. $1 \mathrm{~kW}$ 級 SOFC コジェネシステムの実証試験}

\section{1 システムの仕様}

これまでの成果を基に，2003 年末から $1 \mathrm{~kW}$ 級 SOFC コジェネシステムを関西電力の研究所に設置し発電試験に 取り組まれている。

開発にあたり，発電モジュール，システム自動制御，排 熱利用設備など電力会社としては初めて取り組む内容も多 く，検討すべきことが山積みであったそうである。また， 発電試験のために実際にモジュールを組み立てることで, 細部にわたる技術開発に深く関わることができ，モジュー ル製作にあたっての工夫や課題などを肌で感じることがて きたという。 


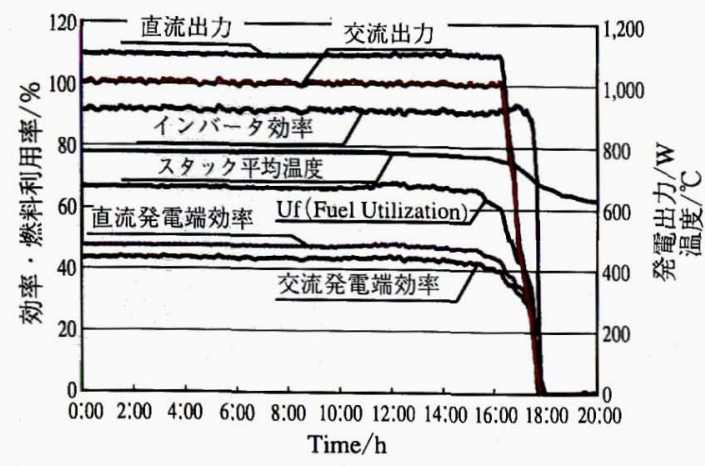

図 9 発電試験データ

$1 \mathrm{~kW}$ 級 SOFC コジェネシステムの目標仕様を以下のよ うに設定している。発電モジュールはスタックュニット 46 段で構成され, インバータ効率 $90 \%$ 以上を考慮して, $1,120 \mathrm{~W}$ の直流出力を定格とする。また燃料には，実用 化の検証のため都市ガス $13 \mathrm{~A}$ を利用し, 交流端発電効率 は LHV*で $40 \%$ 以上を目標とする。排熱回収について は, 高温の排ガスを利用して, 吸収式冷温水器なども利用 できる $90^{\circ} \mathrm{C}$ 温水での回収を目標とする。

このシステムは, 燃料電池部, 制御操作部, 排熱回収部 に分かれている。燃料電池部内のサイズは高さ 1,500 $\mathrm{mm} \times$ 幅 $700 \mathrm{~mm} \times$ 奥行 $650 \mathrm{~mm}$ で, 発電モジュール, 排 ガス配管および弁, 燃料配管, 熱電対および電圧測定線が 納められているが，あくまで試験機ということで余裕を持 った大きさであり実際のものはより小さくなる計画だそう だ。排熱回収装置としては, プレート型熱交換器を利用し て，潜熱回収まで行い回収した温水は $370 l$ の貯湯槽にた められるようにしている。

\section{$4.21 \mathrm{~kW}$ 級 SOFC コジェネシステム発電試験}

2004 年 3 月に行われた交流定格出力 $1 \mathrm{~kW}$ での発電特 性を図 9 に示す。都市ガスを燃料とし，スタック平均温度 $780^{\circ} \mathrm{C}$ において定格出力で安定的に熱自立運転が行えてお り, 内部構造の工夫や改質機能の強化などにより, 交流端 発電効率 $45.1 \%$ (LHV) と非常に高レベルの効率を達成 している。今回開発されたシステムでは, 昇温, 発電, ホ ットスタンバイ，停止，降温など自動制御モードでの検討 も行われており，結果スムーズに自動運転が行えることが 確認されている。システムの実用化という観点からも，完 成に近いことがうかがえる。また，排熱回収試験について

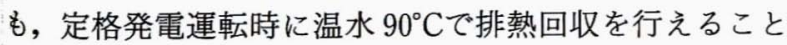
が確認され，潜熱も含めて十分に排熱回収されている。

この発電試験についてある研究者の方は, 「試験装置と いうこともあり，交替で 24 時間体制の監視を行いさまざ

\footnotetext{
* 低位発熱量基準：燃料ガスを完全に燃焼させた時の水蒸気の凝縮潜熱を
} 差し引いた発熱量

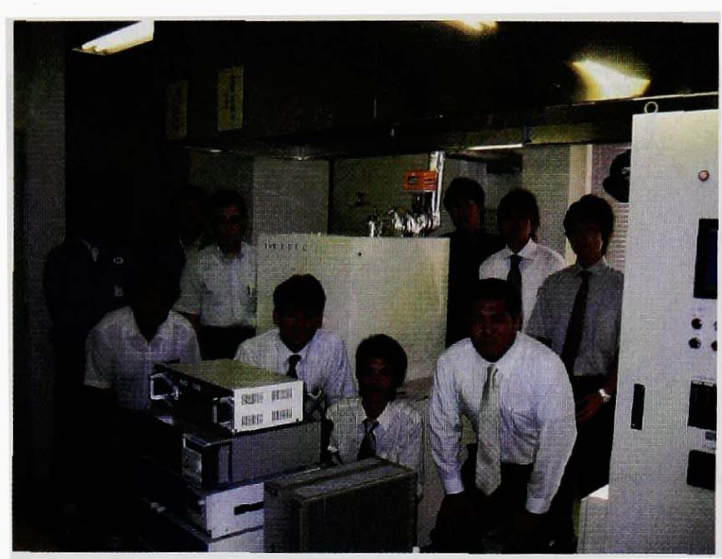

図 10 I kW 級 SOFC コジェネシステムを囲んで

まなトラブルも経験しながら, 最後に最高効率 $45.1 \%$ を 達成することができたことは, 開発している仲間たちの努 力の結晶であり, 成果を出せた達成感は非常に大きなもの であった」と抽しゃっておられ，研究者の方々の熱意， 達成したという自信と誇りを感じることができた。

\section{5.おわりに}

今回の取材を通して以下の知見を得た。

・新しいエネルギーとしての燃料電池の重要性

・ $1 \mathrm{~kW}$ 級 SOFC コジェネシステムの概要

- 研究者の心意気

特に, 新技術の確立過程において, 葛藤し挑戦していく 研究者の方々の目が輝いておられたのが印象に残った。

都市ガスを燃料としたシステム開発や，メーカ技術の検 証のみならず材料開発までを行いながら, 更なる高効率 化, 大容量化に向けて研究を進めておられる研究チームの 取り組みは, 従来の電力会社のイメージとは異なったもの であると感じられ，とても興味深く関心をそそられた。

現在, $3 \mathrm{~kW}$ モジュールにおいて複数スタックの制御技 術などの確立が図られており, 大型化・実用化へ向けて大 きく前進しているそうだ。今後はセルやモジュールの更な る高性能化・大容量化に取り組むとともに, 而久性などの 検証を実施し，2006 年度末を目途に「数十 $\mathrm{kW}$ 級発電シ ステム」の実用化・商品化に取り組み，究極の目標として 火力発電の代替も視野に入れているという。

最後に, 本取材の機会を与えて下さった関西電力研究開 発室の花田氏, 丁寧で分かりやすくご説明下さった関西電 力エネルギー利用技術研究所の山崎氏, 稲垣氏, 西脇氏, 加納氏に，この場を借りて厚く御礼申し上げます。 取材/〈文〉坂口宏睦, 石亀篤司, 藤田剛志, 山本宗義, 東 谷光晴, 柳田将臣 (大阪府立大学大学院) 